\title{
PENGGUNAAN ASAS ULTRA PETITUM PARTIUM: SUATU ANALISIS KRITIS PUTUSAN NOMOR: 253/Pdt.G/2015/MS-KSG
}

\author{
Fatimah Zahara \\ Alumni Prodi Hukum Keluarga Islam \\ Fakultas Syariah IAIN Langsa
}

\begin{abstract}
Decision of the Syar'iyah Kuala Court Judge Number 253 / Pdt.G / 2015 / MS-KSG, which contains the principle of ultra petitum partium, namely the judge grants what is not requested by the plaintiff, if we review the Law Number 253 / Pdt.G / 2015 / MS-KSG this is not permitted by law because if it is done, the judge has passed the authority of ultra vires, and the effect of this decision is declared null and void. When the decision is null and void the impact of the decision is not binding and has not legal consequences and does not have the execution power in it.
\end{abstract}

Keywords: Ultra Petitum Partium, judge's decision, Mahkamah Syar'iyah

Abstrak: Putusan Hakim Mahkamah Syar'iyah Kuala simpang Nomor 253/Pdt.G/2015/MS-KSG, yang mengandung asas ultra petitum partium yakni hakim mengabulkan apa yang tidak diminta oleh penggugat, jika kita tinjau dari Undang-Undang Nomor 253/Pdt.G/2015/MS- KSG hal ini tidak dibolehkan dalam hukum beracara karena jika dilakukan maka hakim telah melewati kewenangan ultra vires, dan dampak dari putusan ini dinyatakan batal demi hukum. Ketika putusan itu batal demi hukum dampaknya putusan itu tidak mengikat dan tidak ada akibat hukum serta tidak memiliki daya eksekusi didalamnya.

Kata kunci: Ultra Petitum Partium, Putusan Hakim, Mahkamah Syar'iyah

\section{Pendahuluan}

Perceraian biasanya lebih banyak mendatangkan dampak negatif dibandingkan dengan dampak Positif. ${ }^{1}$ Dengan perceraian konflik antara suami istri mungkin bisa terselesaikan akan tetapi akibat perceraian tersebut perhatian terhadap anak-anak akan menjadi berkurang serta hubungan antar keluarga besar kedua belah pihak akan menjadi retak. Oleh karenanya perceraian hanya dibenarkan apabila meneruskan perkawinan lebih besar mudharatnya bila dibandingkan dengan memutuskan perkawinan tersebut. Anaklah yang akan menjadi korbannya.

Dalam pemeliharaan hak asuh anak sering terjadi pertengkaran karena keduanya saling ingin memiliki hak asuh anak (hadhanah). Oleh karena itu untuk menyelesaikan permasalahan perceraian dan hak asuh anak (hadhanah) di selesaikan di

\footnotetext{
${ }^{1}$ M.fauzan, Pokok-Pokok Hukum Acara Perdata Peradilan Agama Dan Mahkamah Syar'iyah Di Indonesia, (Jakarta: Kencana, 2007), hal. 57
}

Pengadilan Agama atau Mahkamah Syar'iyah tempat tinggal istri terakhir. ${ }^{2}$

Sebelum melangsungkan persidangan hal yang pertama di lakukan oleh Penggugat atau Pemohon adalah membuat surat gugatan yaitu yang berisi posita dan petitum mengenai identitas Pemohon dan Termohon dan berisi dengan dalil dalil yang ingin Pemohon minta diadilkan oleh Hakim yang mengadilinya. Dalam hal ini hakim diberikan kekuasaan yaitu sesuai Undang-Undang Nomor Republik Indonesia Nomor 4 Tahun 2004 tentang kekuasaan kehakiman dibagian Bab I Ketentuan Umum Pada Pasal I ayat 1 disebutkan bahwa Kekuasaan Kehakiman adalah Kekuasaan Negara Yang Merdeka Untuk Menyelenggarakan Peradilan Guna Untuk Menegakkan Hukum Dan Keadilan Berdasarkan Pancasila, Demi Terselenggaranya Hukum Republik Indonesia.

Penyelenggaran kekuasaan kehakiman di serahkan kepada badan-badan peradilan yang di

\footnotetext{
${ }^{2}$ M.fauzan, Pokok-Pokok Hukum Acara Perdata, hal. 57
}

Penggunaan Asas Ultra Petitum Partium | 31 
tetapkan Undang-Undang. Peradilan adalah Kekuasaan negara dalam menerima, memeriksa, mengadili, memutus dan menyelesaikan perkara untuk menegakkan Hukum dan Keadilan. ${ }^{3}$

Larangan untuk mengadili dan memutuskan suatu perkara yang tidak di tuntut di dalam petitum gugatan yang di jelaskan dalam pasal HIR 178/RBG 189 pada ayat tiga (3) yang merupakan hukum acara yang berlaku di Pengadilan Negeri dan Pengadilan Agama di Indonesi. ${ }^{4} \mathrm{Hal}$ ini dapat di pahami, karena inisiatif untuk mempertahankan atau tidak adalah salah satu hak yang bersifat privat yang di miliki individu atau perorangan yang terletak pada kehendak atau pertimbangan orang atau perorangan tersebut yang tidak dapat di lampaui, karena ultra petitum pertium di larang dengan alasan salah menerapkan atau melanggar hukum yang berlaku. Jika ada suatu putusan yang terdapat mengadung ultra petitum partium maka putusan itu nyatakan batal demi hukum meskipun hal itu yang dilakukan hakim dengan niat baik. ${ }^{5}$

Dalam putusan Hakim Mahkmah Syar'iyah Kuala simpang dengan Nomor Perkara 253/Pdt.G/2015/MS-KSG Hakim menggunakan hak ex officio yang mengenai cerai gugat permasalahannya tentang hak asuh anak (hadhanah). gugatan Nomor Perkara 253/Pdt.G/2015/MS-KSG bagian petitumnya penggugat tidak mencantumkan hak asuh anak ( hadhanah ) untuk diadilkan dan dijatuhkan kepada penggugat. Namun Hakim mengabulkan apa yang tidak diminta oleh penggugat, bukan kah ini mengandung ultra petitum partium.

Berdasaarkan uraian diatas, maka yang perlu dibahas dalam tulisan adalah mengenai Ultra petitum partium ultra petitum partium dalam putusan hakim mahkamah syar'iyah kuala simpang tentang cerai gugat (studi analisis putusan nomor 253/pdt.g/2015/ms-ksg).

\footnotetext{
${ }^{3}$ Abdul Ghofar Anshori, Peradilan Agama di indonesia pasca undang-undang nomor 3 Tahun 2006 sejarah kedudukan dan kewenangan, (yogyakarta:UII Press, 2007), hal.147

${ }^{4}$ Abdul Manan, Penerapan Hukum Acara Perdata di Lingkungan Peradilan Agama, hal.112

${ }^{5}$ Sudikno Mertokosumo, Hukum Peradilan Perdata Indonesia (Yogyakarta: Liberti, 1999), hal.5
}

\section{Pengertian Putusan}

Putusan menurut dalam bahasa arab berasaldari kata "al-qadha" yang artinya keputusan dan jamaknya adalah "aqdhiyyah" yang menurut asalmuasal artinya adalah dikatakan untuk menyempurnakan sesuatu dan menetapkan hukumnya, menyelesaikannya dan memutuskannya. Dikatakan demikian karena hakim dimintakan untuk menyempurnakan suatu urusan dan menetapkan hukumnya menyelesaikannya, dan memutuskannya, sementara itu, "al-qadhâ"dibaca panjang mempunyai arti keputusan hukum antara sesama manusia. Al-qadha menurut asalnya dikatakan untuk menyempurnakan sesuatu,dan menetapkan hukumnya, menyelesaikannya dan menuntaskannya, disebut demikian karena Hakim menyempurnakannya suatu urusan dan menetapkan hukumnya, menyelesaikannya dan menuntaskannya. ${ }^{6}$

Sedangkan menurut istilah "syara" ialah memisahkan sengketa gugatan dan menyelesaikan, serta memutuskan pertentangan. Keputusan menurut istilah bahasa Belanda dikenal dengan istilah "vonis" dan "gewijsde". Adapun pengertian vonis adalah putusan yang belum mempunyai kekuatan hukum pasti sehingga masih ada peluang upaya hukum biasa, sedangkan gewijsde adalah putusan yang telah mempunyai kekuatan hukum yang pasti, sehingga hanya dimungkin upaya hukum khusus. Vonis sering disebut juga dengan "voorlopiggewjside" sedangkan gewjside disebut dengan "terlijskgewijside".

\section{Kekuatan Hukum Putusan}

Setelah terjadinya Putusan maka Putusan tersebut mempunyai nilai kekuatan yang di pandang didalam mata hukum. Adapun kekuatan Putusan Pengadilan memiliki 3 kekuatan yaitu:

\section{a. Kekuatan Mengikat}

Putusan yang telah memperoleh kekuatan hukumyang tetap tidak dapat di ganggu gugat lagi Putusan yang telah mempunyai kekuatan pasti

${ }^{6}$ Ahmad Mujahidin, Pembaharuan Hukum Acara Peradilan Agama, (Bogor: Ghalia Indonesia, 2012), hal. 22

${ }^{7}$ Ahmad Mujahidin,Pembaharuan Hukum Acara Peradilan Agama, hal. .229

Penggunaan Asas Ultra Petitum Partium | 32 
bersifat mengikat. Sifat mengikat dari Putusan itu bertujuan untuk menetapkan suatau hak atau suatu hubungan hukum antara pihak-pihak yang berpekara. ${ }^{8}$

\section{b. Kekuatan Pembuktian}

Asas nilai kekuatan Pembuktian yang melekat pada Putusan sejalan dengan sifat kekuatan mengikat yang melekat pada setiap Putusan Pengadilan dengan sendirinya menurut hukum. Sebagaimana yang telah diterangkan sebelumnya bahwa putusan harus dibuat secara tertulis. Tujuan adalah untuk dapat dipergunakan sebagai alat bukti oleh para pihak yang mungkin dipergunakan untuk keperluan banding,kasasi Putusan tersebut bisa dijadikan akta autentik yang dapat digunakan sebagai alat bukti. ${ }^{9}$

\section{c. Kekuatan Eksekutorial}

Putusan yang telah memperoleh kekuatan hukum yang tetap atau memperoleh kekuatan yang pasti, Putusan Pengadilan itu baru dapat dilaksanakan apabila ada titel eksekutorial yang berbunyi"Demi Keadilan Berdasarkan Ketuhanan Yang Maha Esa" apabila tidak di cantumkan katakata tersebut maka Putusan yang dijatuhkan oleh Hakim itu tidak dapat dilakanakan eksekusinya. Jika dalam Putusan tercantum amar yang bersifat comdemnatoir,maka dalamPutusan tersebut melekat kekuatan eksekutorial yaitu yang mempunyai kekuatan hukum yang tetap.$^{10}$

\section{Ultra Petitum Dalam Perspektif Hukum}

Ultra petitum partium adalah hukum formil mengandung pengertian penjatuhan Putusan atas perkara yang tidak dituntut atau mengabulkan lebih dari apa yang dituntut. Ultra petitum sendiri banyak dipelajari di bidang hukum perdata dengan keberadaan keadilan perdata yang lebih tua berdiri sendiri sejak di tetapkan kekuasaan kehakiman di indonesia. Di dalam perkara pengujian Undang-

${ }^{8}$ M.Yahya Harahap, kedudukan Kewenangan Dan Acara Peradilan Agama, (Jakarta: Sinar Grafika, 2001).hal.310

${ }^{9}$ Abdul Manan, Penerapan Hukum Acara Perdata di Lingkungan Peradilan Agama, hal.309

${ }^{10}$ M.Yahya Harahap, Kedudukan Kewenangan Dan Acara Peradilan Agama, hal.311
Undang oleh Mahkamah Konsitusi menjadi pemilik dengan digunakan ultra petitum partium dalam beberapa Putusan. ${ }^{11}$

Supaya gugatan sah dalam arti tidak ada cacat formil, makadalam gugatan tersebut harus dicantum kan apa saja yang ingin diminta untuk diadilkan oleh hakim. Yang harus dicantumkan dalam petitum gugatan ialah yang berisi pokok tuntutan penggugat, yang berupa deksripsi yang jelas menyebutkan satu persatu dalam akhir gugatan tentang hal-hal apa saja yang menjadi pokok tuntutan Penggugat yang harus dinyatakan dan dibebankan kepada Tergugat. Dengan kata lain petitum gugatan, yang berisi tuntutan atau permintaan kepada pengadilan untuk dinyatakan dan ditetapkan sebagai hak penggugat atau hukuman kepada tergugat atau kedua belah pihak.

Apabila dalam surat gugatan telah memehuni syarat yaitu posita dan petitumnya jelas maka gugatan itu bisa di terima namun, jika dalam gugatan tersebut tidak memenuhi syarat formil dalam petitum dan posita maka gugatan itu mengandung cacat formil, sehingga harus dinyatakan gugatan tidak dapat diterima. Supaya petitum tidak menimbulkan cacat formil gugatan, akan dikemukakan secara ringkas berbagai hal yang menyebabkan petitum bertentangan dengan tata tertib beracara yaitu. ${ }^{12}$ Tidak menyebutkan secara tegas apa yang diminta atau petitum bersifat umum apa yang diminta penggugat. ${ }^{13}$ Oleh karena itu, jika petitum sifatnya kabur karena tidak jelas secara spesifik apa yang diminta, meyebabkan gugatan itu obscuur libel, yang berakibat gugatan tidak dapat diterima. Demikian ditegaskan dalam salah satu putusan MA, kemudian petitum yang meminta agar Peradilan menghukum tergugat supaya tidak mengambil tindakan yang bersifat merusak bangunan adalah petitum yang bersifat negatif, oleh karena itu dapat dikabulkan. Demikian penegasan dalam salah satu putusan MA, serta masalah yang harus di perhatikan,gugatan harus sejalan dengan dalil gugatan. Dengan demikian, petitum mesti

${ }^{11}$ Martinus Sahrani dan Ilham Gunawan, Kamus Hukum, (Jakarta: RestuAgung 2002), hal.154

${ }^{12}$.M. Yahya Harahab, Hukum Acara Perdata, hal,..63

${ }^{13}$ M.Yahya Harahab, Hukum Acara Perdata, hal,...63 Penggunaan Asas Ultra Petitum Partium | 33 
bersesuai atau konsisten dengan dasar hukum dan fakta-fakta yang dikemukakan dalam posita. ${ }^{14}$

Dengan penjelasan di atas jelas bahwa dalam membuat gugatan harus diperhatikan dengan seksama mungkin,demikian juga hal nya dengankim,bukan hanya penggugat yang harus memperhatikan gugatan itu sendiri hakim juga demikian, hakim wajib mengadili seluruh bagian gugatan yang telah di jelaskan dalam pasal 178 ayat (2) HIR, pasal 189 ayat (2) RBG, putusan harus total dan menyeluruh memeriksa dan mengadili setiap segi gugatan yang diajukan. Tidak boleh hanya memeriksa dan memutuskan sebagian saja, dan mengabaikan gugatan selebihnya. Cara mengadili yang demikian bertentangan dengan asas yang digariskan Undang-Undang. Dan hakim juga tidak boleh mengabulkan melebihi apa yang dituntut, dalam hal ini telah dijelaskan pada HIR Dan RBG pasal 178 ayat (3) dan 189 ayat (3), Hakim tidak boleh mengabulkan melebihi apa yang dituntut yang dikemukakan dalam gugatan. Larangan ini disebut Ultra Petitum Partium, jika ada putusan yang mengadung ultra petitum partium maka putusan tersebut termasuk putusan yang sah namun batal demi hukum yaitu dalam arti tidak mempunyai hukum yang tetap, meskipun Hakim melakukan hal itu dengan niat atau beritikad baik maupun sesuai dengan kepentingan umum mengadilkan dengan cara mengabulkan melebihi dari apa yang digugat, dapat dipersamakan dengan tindakan yang tidak sah (ilegal) meskipun dilakukan dengan iktikad baik. Oleh karena itu, Hakim yang melanggar prinsip ultra petitum partium, sama dengan pelanggaran terhadap prinsip rule of law yaitu, karena tindakan itu tidak sesuai dengan prinsip rule of law, semua tindakan hakim mesti dengan hukum (accordance with the law), kemudian tindakan hakim yang mengabulkan melebihi dari yang di tuntut, nyata-nyata melampaui batas wewenang yang diberikan pasal 178 ayat (3) HIR kepadanya, padahal sesuai dengan priinsip rule of law, siapapun tidak boleh melakukan tindakan yang melampaui batas

\footnotetext{
${ }^{14}$ M.Yahya Harahab, Hukum Acara Perdata, hal,..63
}

wewenangnya. ${ }^{15}$ Hal tersebut dapat membuat batal demi hukum.

\section{Dampak Putusan Ultra Petitum Partium}

Setiap putusan Pengadilan Agama harus dibuat hakim dalam bentuk tertulis dan ditandatanggani Oleh hakim ketua dan hakim-hakim anggota yang ikut memeriksa perkara sesuai dengan penetapan Majelis Hakim yang dibuat oleh Ketua Pengadilan Agama, serta ditandatanggani pula oleh Panitera Penganti yang ikut sidang sesuai penetapanpanitera, (pasal 23 ayat (2) Undang-Undang Nomor 14 Tahun 1970), Apa yang diucapakan oleh hakim dalam sidang haruslah benar-benar sama dengan apa yang tertulis, dan apa yang dituliskan harus benar-benar sama dengan apa yang diucapkan dalam sidang pengadilan. ${ }^{16}$

Dalam putusan yang bersifat perdata, UndangUndang HIR pasal 178 ayat (2) dan 189 ayat (2) mewajibkan para Hakim untuk mengadili semua tuntutan sebagaimana tersebut dalam surat gugatan. ${ }^{17}$ Hakim juga dilarang menjatuhkan putusan terhadap sesuatu yang tidak dituntut sebagaimana yang telah di jelaskan dalam pasal 178 ayat(3) HIR dan pasal 189 RBG ayat (3) yang mengatakan bahwa Hakim tidak boleh mengabulkan apa yang tidak diminta, jika hal ini terjadi dalam persidangan maka putusan nya akan mengadung asas ultra petitum partium yaitu mengabulkan apa yang tidak di tuntut oleh pengugat di dalam petitumnya, jika hakim mengabulkan apa yang tidak di mintakan oleh penggugat maka hakim akan di katagorikan dalam telah melanggar kewenangan ultra vires. yaitu kewenangan yang dimiliki oleh Hakim dalam beracara persidangan. Sehubungan dengan itu, sekiranya tindakan ultra petitum itu lakukan hakim berdasarkan alasan iktikad baik, tetapi tidak dapat dibenarkan atau ilegal. Karena melanggar prinsip the rule of law (the principal of the rule of law), oleh karena itu tidak dapat dibenarkan. Hal itupun ditegaskan dalam putusan MA No.1001 K/Sip/1972 yang melarang hakim mengabulkan hal-hal yang tidak diminta atau melebihi apa yang tidak diminta.

\footnotetext{
${ }^{15}$ M.Yahya Harahab, Hukum Acara Perdata, hal,..802

${ }^{16}$ Abdul Manan, Penerapan Hukum Acara Perdata di Lingkungan Peradilan Agama, hal.292

${ }^{17}$ Abdul Manan, Penerapan Hukum,..hal. 292 Penggunaan Asas Ultra Petitum Partium | 34
} 
Yang dapat dibenarkan paling tidak putusan yang dijatuhkan hakim, masih dalam kerangka yang serasi dengan gugatan. Demikian Penegasan Putusan MA No. 556 K/Sip/1971. ${ }^{18}$

Putusan judex facti yang berdasarkan pada petitum subsidair yang berbentuk ex aequo et bono, dapat dibenarkan asal masih dalam kerangka yang sesuai dengan inti primair. Bahkan terdapat juga putusan yang lebih jauh dari itu. Dalam putusan MA No.556 K/Sip/1971, dimungkin mengabulkan gugatan yang melebihi permintaan dengan syarat asal masih sesuai dengan kejadian materiil. Namun perlu diingat, penerapan yang demikian sangat berat. Akan tetapi sebaliknya dalam hal pettitum primair dan subsidair masing -masing dirinci satu persatu, tindakan Hkim yang mengabulkan sebagian pettitum primair dan sebagai lagi putusan subsidair, dianggap tindakan yang melampaui batas-batas wewenang. Oleh karena itu tidak dibenarkan. Demikian penegasan putusan MA No.882 K/Sip/1974. Dalam hal gugatan mencantumkan pettium primair dan subsidair, pengadilan hanya dibenarkan memilih satu diantaranya, apakah mengabulkan pettium atau subsidair. Hakim tidak dibenarkan menggunakan kebebasan cara mengadili dengan jelas mengabulkan pettitum primair atau mengambilkan sebagian dari petitum subsidair. Apakah mengabulkan sesuatu yang sama sekali tidak diajukan dalam petitum nyata-nyata melanggar asas ultra petitum, oleh karena itu harus dibatalkan. Seperti yang dikemukakan dalam putusan MA No.77 K/Sip/1973. Putusan harus dibatalkan, karena putusan PT mengabulkan Ganti rugi yang tidak diminta dalam gugatan. Begitu juga putusan pengadilan didasarkan atas pertimbangan yang menyimpang dari dasar gugatan, menurut Putusan MA No.372 K/Sip/1970 harus dibatalkan. ${ }^{19}$ Dari penjelasan tersebut sangat lah jelas bahwa putusan yang mengandung asas ultra petitum dampaknya akan tidak sah putusan tersebut. Jika putusan ada unsur Ultra Petitum Partium maka putusan itu juga bisa dikatagorikan putusan itu dinyatakan batal demi hukum.

\footnotetext{
${ }^{18}$ M.Yahya Harahab, Hukum Acara Perdata,..hal. 802

${ }^{19}$ M.Yahya Harahab, Hukum Acara Perdata hal,..803
}

\section{Bentuk Putusan Ultra Petitum Partium dalam Putusan Perkara Nomor 253/Pdt.G/2015/MS- KSG}

Adapun isi bentuk putusan dalam Nomor Perkara 253/Pdt.G/2015/MS-KSG ialah memiliki asas ultra petitum partium, didalam putusan tersebut Hakim mengabulkan apa yang tidak diminta oleh Penggugat. Hal ini tidak dibolehkan dalam hukum beracara yaitu dalam pasal 178 ayat 3 HIR dan 189 ayat 3 RBG menyatakan bahwa "Hakim tidak boleh mengabulkan apa yang tidak dituntut oleh penggugat atau pemohon", jika Hakim melakukan hal ini dalam Persidangan maka Hakim Telah melanggar Kewenangan Ultra Vires. ${ }^{20}$

Adapun yang dikabulkan oleh Hakim Mahkamah Syar'iyah Kualasimpang dalam Putusan Nomor 253/Pdt.G/2015/MS-KSG ialah Hak asuh Anak (Hadhanah), didalam isi gugatan dan bagian petitum gugatannya penggugat tidak meminta Hak Asuh Anak untuk dijatuhkan kepadanya, namun Hakim mengabulkan bahwasanya Hak Asuh Anak (Hadhanah) dijatuhkan pada si Penggugat hal ini tidak sesuai dengan Undang-Undang yang berlaku dalam hukum acara perdata pada pasal 178 ayat 3 189 ayat 3 RBG yang menyatakan bahwa "Hakim tidak boleh mengabulkan melebihi apa yang diminta oleh si Penggugat atau sipemohon". Dalam hal ini Hakim tidak boleh melakukan apa yang dilarang dalam hukum beracara walaupun Hakim melakukan itu dengan niat baik namun tetap dinamakan melanggar kewenangan Ultra Vires. Dengan demikian Putusan perkara Nomor 253/Pdt.G/2015/MS-KSG mempunyai kelemahan yaitu putusan tersebut mengandung asas ultra petitum partium. Ketika putusan mempunyai asas ultra petitum partium maka putusan tersebut dinyatakan batal demi hukum.

\section{Dampak Hukum Terhadap Putusan Ultra Petitum Partium dalam Putusan Perkara Nomor 253/Pdt.G/2015/MS-KSG}

Setelah melihat kasus Cerai gugat pada perkara Nomor 253/Pdt.G/2015/MS-KSG antara Penggugat (istri) dan Tergugat (suami) yang permasalahan dalam Nomor perkara tersebut adalah hak asuh

\footnotetext{
${ }^{20}$ M.Yahya Harahab, Hukum Acara Perdata,.. hal.501 Penggunaan Asas Ultra Petitum Partium | 35
} 
anak (Hadhanah). Penulis melihat bahwa putusan perkara tersebut memiliki dampak hukum. Adapun yang menjadi dampak hukum Terhadap putusan perkara Nomor 253/Pdt.G/2015/MS-KSG ialah Putusan tersebut adalah mengandung asas Ultra Petitum Partium dan ketika putusan mengandung asas ultra petitum partium maka putusan tersebut dinyatakan batal demi hukum dan tidak memiliki kekuatan dan akibat hukum. Dengan demikian yang menjadi putusan perkara Nomor 253/Pdt.G/2015/MS-KSG mengandung asas ultra petitum partium Hakim mengabulkan apa yang tidak diminta oleh penggugat namun Hakim mengabulkannya.

Adapun didalam isi gugatan penggugat (istri) tidak meminta bahwasanya Hak Asuh Anak (hadhanah) jatuh kepadanya namun Hakim menjatuhkan putusan Hak asuh Anak (hadhanah) jatuh kepada nya. Jika kita tinjau dari UndangUndang HIR (Het Herziene Indonesisch Reglement) dan RBG (Rechtreglemenet voor de Buitengewesten) pasal 178 ayat 3 dan 189 ayat 3 bahwa" Hakim tidak boleh mengabulkan apa yang tidak dituntut oleh Penggugat atau Pemohon" maka hakim melanggar Undang-Undang ini, Namun Hakim juga memiliki ex officio kerena jabatan yang ia miliki yaitu mengabulkan apa yang tidak diminta oleh penggugat berdasarkan jabatan nya namun putusan ini akan batal demi hukum karena hakim bisa menggunakan ex officionya jika berhubungan langsung dengan perkara contohnya nafkah 'iddah dan mut'ah. Karena itu wajib diberikan oleh mantan suami untuk mantan istri walaupun siistri tidak memintanya lewat petitum gugatan. Perkara yang diatas ialah mengenai Hak suh asuh anak (hadhanah) setiap orang tua pasti menginginkan hak asuh anak jatuh kepadanya. Oleh sebab itu harus dicantumkan kedalam petitum gugatan supaya dapat di kabulkan hakim dan putusan itu dianggap ada dan mempunyai kekuatan serta mempunyai akibat hukum didalamnya dan tidak batal demi hukum.

Pemeliharaan anak merupakan salah satu tujuan syara' yaitu menjaga keturunan (hifz al-nasl), pemeliharaan anak memang mengandung arti sebuah tanggung jawab orang tua untuk mengawasi, memberikan pelayanan yang semestinya serta mencukupi kebutuhan hidup anak dari orangtuanya dan sebagai orang tua juga harus memberikan pelayanan dan kebutuhan si anak sebagaimana maksud dalam pasal 9 Undang-Undang Nomor 4 Tahun 1979 tentang Kesejahteraan Anak menyebutkan bahwa, orang tua adalah yang pertama-tama bertanggung jawab atas terwujudnya Kesejahteraan Anak baik secara fisik, jasmani maupun sosial. Tanggung jawab orang tua adalah atas kesejahteraan anak mengandung kewajiban memelihara dan mendidik anak sedemikian rupa, sehingga anak dapat tumbuh dan berkembang menjadi orang yang cerdas, sehat, berbakti kepada orang tua, berbudi pekerti luhur, dan bertakwa kepada Tuhan Yang Maha Esa.

Dalam konteks ini Hakim memang memutuskan perkara diatas bertujuan baik yaitu melihat akan akibat kesejahteraan dan perlindungan anak-anak Penggugat dan Tergugat itu lebih baik dengan si penggugat di bandingkan dengan Tergugat. Namun hal ini tidak dibenarkan walaupun alasan hakim dengan bentuk apapun tetap saja putusan itu akan batal demi hukum dan tidak mengikat dan tidak ada akibat hukum didalamnya.

Supaya putusan itu tidak batal demi hukum alangkah bagusnya dicnatumkan apa saja yang inggin diminta untuk diadilkan oleh hakim maka dicantumkan di dalam petitum gugatan karena itu sangatlah berpengaruh untuk putusan supaya putus itu tidak batal demi hukum.

\section{Penutup}

Berdasarkan hasil penilitian terhadap putusan Nomor 253/Pdt.G/2015/MS-KSG tentang cerai gugat permasalahannya adalah Hak Asuh Anak (Hadhanah) yang telah penulis uraikan pada bab sebelumnya, maka dapat ditarik kesimpulan sebagai berikut: Pada putusan perkara cerai gugat Nomor 253/Pdt.G/2015/MS-KSG Hakim Mahkamah Syar'iyah Kuala Simpang memutuskan bahwa hak asuh anak (Hadhanah) jatuh kepada penggugat padahal penggugat tidak meminta didalam gugatannya mengenai Hak asuh Anak Jatuh kepadanya, hal ini melanggar asas ultra petitum partium yang ada dalam Undang-Undang 178 ayat 3 HIR dan 189 ayat 3 RBG bahwasanya "Hakim tidak boleh mengabulkan apa yang tidak dituntut 
oleh penggugat atau pemohon". Jika hal ini dilakukan oleh Hakim maka Hakim telah melanggar kewenangan ultra vires.

\section{DAFTAR PUSAKA}

Ghofar Anshori, Abdul, Peradilan Agama di Indonesia Pasca Undang-Undang Nomor 3Tahun 2006 Sejarah Kedudukan Dan Kewenangan, (Yogyakarta: UII Press,2007)

Abdul Manan, Penerapan Hukum Acara perdata di Lingkungan peradilan Agama, (Jakarta: Kencana, 2008)

Ahmad Mujahidin, Pembaharuan Hukum Acara Peradilan Agama, (Bogor: Ghalia Indonesia, 2012)

Al- Ghazali, Al-Mustashfa Fii 'Ilmi Ushuli. (Beirut: Daar Al- kutub Al-Ilmiyah, 1993)

Aris Bintania, Hukum Acara Peradilan Agama Dalam Kerangka figh al-Qadha, (Jakarta: Raja Grafindo Persada, 2013)

Gemala Dewi, Hukum Acara perdata Di Indonesia, (Jakarta: Kencana,2005)

M. Fauzan, Pokok-Pokok Hukum Acara Perdata Peradilan Agama Dan Mahkamah Syar'iyah di Indonesia, (Jakarta: Kencana, 2007)

M.Yahya Harahap, Hukum Acara Perdata, (Jakarta: Sinar Grafika, 2005)

Kedudukan Kewenangan Dan Acara Peradilan Agama,Jakarta:Sinar Grafika,2001

Martinus Sahrani dan Ilham Gunawan, Kamus Hukum, (Jakarta: Restu Agung, 2002) 